Aspects of Illegal, Unreported and Unregulated Fishing in the Southern Ocean 
Reviews: Methods and Technologies in Fish Biology and Fisheries VOLUME 5

Series editor:

Jennifer L. Nielsen

U.S. Geological Survey,

Biological Resources Division,

Anchorage, Alaska 


\section{Aspects of Illegal, Unreported and Unregulated Fishing in the Southern Ocean}

by

Rachel J. Baird

University of Queensland,

Brisbane, QLD, Australia

照 Springer 
A C.I.P. Catalogue record for this book is available from the Library of Congress.

ISBN-10 1-4020-5338-X (HB)

ISBN-13 978-1-4020-5338-2 (HB)

ISBN-10 1-4020-5339-8 (e-book)

ISBN-13 978-1-4020-5339-9 (e-book)

Published by Springer,

P.O. Box 17, 3300 AA Dordrecht, The Netherlands.

www.springer.com

Cover photo: Dissostichus eleginoides (Patagonian Toothfish)

Printed on acid-free paper

All Rights Reserved

(c) 2006 Springer

No part of this work may be reproduced, stored in a retrieval system, or transmitted

in any form or by any means, electronic, mechanical, photocopying, microfilming, recording or otherwise, without written permission from the Publisher, with the exception

of any material supplied specifically for the purpose of being entered

and executed on a computer system, for exclusive use by the purchaser of the work. 
Wild is the cry of the sea in the caves by it-

Sea that is smitten by the spears of the snow;

Desolate songs are the songs of the waves by it-

Down in the south where the ships never go.

(Extract from Beyond Kerguelen by Henry Kendall. H. Kendall, Leaves from an Australian ForestPoetical Works of Henry Kendall (1869). This poem was written following a whaling trip in 1853 to the Southern Ocean by 14 year old Henry Kendall. 


\section{Table of Contents}

Abstract

Acknowledgements $\quad$ xV

Abbreviations $\quad$ xvii

Tables, Graphs and Maps $\quad$ xix

PART 1 The Problem of IUU Fishing 1

Introduction 3

Chapter 1 The Impact of IUU Fishing on Marine Fisheries 5

1.1 The Physical and legal State of Marine Fisheries 5

$\begin{array}{ll}1.1 .1 \text { Overfishing } & 5\end{array}$

1.1.2 The Role of International Law $\quad 6$

1.2 Understanding IUU Fishing 9

1.3 Global Attention on the problem of IUU fishing 13

1.4 Gaining Momentum in the International Response to IUU Fishing 14

$\begin{array}{ll}\text { 1.4.1 A Blueprint for Action } & 15\end{array}$

1.4.2 The Code of Conduct and Compliance Agreement 16

1.4.3 The Persistence of IUU and the Adoption of the IPOA-IUU 17

$\begin{array}{ll}\text { 1.4.4 Recent International Meetings } & 18\end{array}$

$\begin{array}{ll}1.5 & 1 \\ 1.6\end{array}$

1.6 The Experience of IUU Fishing in the Southern Ocean 21

1.6.1 Emerging Concerns about IUU Fishing in CCAMLR Waters 21

1.6.2 IUU Fishing in the CCAMLR Waters in the $21^{\text {st }}$ Century 22

1.6.3 The CCAMLR Response $\quad 23$

1.6.4 The Australian Response $\quad 24$

1.7 Why IUU Fishing Developed and Persists 25

$\begin{array}{lll}1.8 \text { Conclusion } & 27\end{array}$

PART 2 Factors Contributing to the Development and Persistence 29 of IUU Fishing

Introduction 31

Chapter 2 Legal Factors Contributing to the Development of IUU Fishing 35

2.1 Legal Factors influencing the Development and Practice of High Seas Fisheries and the Emergence of IUU Fishing 
2.2 The Development of the Freedom of the High Seas 36

2.2.1 The Influence of Hugo Grotius 36

2.2.2 Defending the High Seas Freedom and its Codification 40

2.2.3 Achieving responsible fishing on the high seas 42

2.2.4 Regulating the Freedom of the High Seas 44

Flag State Responsibilities $\quad 44$

The Tragedy of the Commons $\quad 45$

2.2.5 Flag State Authority $\quad 47$

$\begin{array}{ll}\text { The Nationality of Ships } & 47\end{array}$

Genuine Link Requirement $\quad 50$

Attributing some meaning to the Genuine Link Requirement 53

$\begin{array}{ll}\text { Flags of Convenience } & 58\end{array}$

$\begin{array}{ll}\text { 2.2.6 PactaTertii } & 63\end{array}$

Summary of Legal Factors contributing to IUU Fishing 64

Chapter 3 Economic and Political Factors influencing the development 65 and practice of High Seas Fisheries and the emergence of IUU Fishing

3.1 Introduction

3.2 Low Risk of Apprehension v. High Economic Returns

3.3 Capital Investment and Increases in Technology 67

$\begin{array}{ll}3.4 & \text { The over-exploitation of Living Resources }\end{array}$

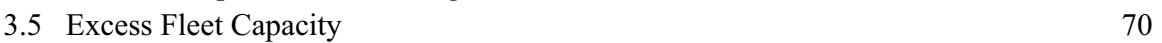

$\begin{array}{lll}3.6 & \text { Subsidies } & 72\end{array}$

$\begin{array}{lll}3.7 & \text { Extension of Coastal State Sovereignty } & 74\end{array}$

3.8 The Entry of Corporate Criminals into IUU Fishing 76

3.9 Summary of Non-legal Factors contributing to IUU Fishing 78

$\begin{array}{ll}3.10 \text { Conclusion } & 79\end{array}$

PART 3 International Measures $\quad 81$

Introduction $\quad 83$

Chapter 4 International Law Applicable to IUU Fishing 85

4.1 The Code of Conduct $\quad 85$

4.2 The FAO Compliance Agreement 86

4.2.1 Flag State Responsibility $\quad 87$

4.2.2 Port State Control $\quad 88$

4.2.3 Records of fishing Vessels and Exchange of Information 89

4.2.4 Duty to Cooperate and the role of RFMOs 92

4.3 The UN Fish Stocks Agreement 93

$\begin{array}{lr}\text { 4.3.1 Flag State Controls } & 94\end{array}$

4.4 Port State Controls 95

4.4.1 Records of Fishing Vessels and Exchange of Information 95

4.4.2 Duty to Cooperate and the role of RFMOs 96 
4.5 The Application of the Compliance Agreement and UN Fish Stocks Agreement 97

4.6 IPOA-IUU

4.6.1 Flag State Controls

4.6.2 Port State Controls

100

4.6.3 Records of Vessels and Exchange of Information 102

4.6.4 Duty to Cooperate and the role of RFMOs 102

$\begin{array}{ll}\text { 4.6.5 Market State or Trade Controls } & 103\end{array}$

$\begin{array}{ll}\text { 4.6.6 Coastal State Obligations } & 104\end{array}$

4.7 Recent International Meetings addressing IUU Fishing 105

4.8 The State of International Treaty and Customary Law 106

4.8.1 Acknowledging Flag State Responsibility 106

$\begin{array}{ll}\text { 4.8.2 Port State controls } & 107\end{array}$

4.8.3 Records of Vessels and Exchange of Information 111

4.8.4 Duty to Cooperate and the role of RFMOs 112

4.8.5 Market State or Trade Controls 114

4.8.6 National Measures $\quad 115$

$\begin{array}{ll}4.9 \text { Conclusion } & 116\end{array}$

Annex A to Chapter $4 \quad 117$

$\begin{array}{lll}\text { PART } 4 & \text { Regional Measures: CCAMLR } & 121\end{array}$

$\begin{array}{ll}\text { Introduction } & 123\end{array}$

Chapter 5 CCAMLR Management in the Southern Ocean 125

5.1 An Introduction to the CCAMLR structure 125

$\begin{array}{ll}5.2 \text { Maritime zones in the Southern Ocean } & 127\end{array}$

5.2.1 CCAMLR Area of Application $\quad 127$

5.2.2 Coastal State Claims in the Southern Ocean 130

5.2.3 The Relevance of the Chairman's Statement 131

5.2.4 The Relevance of Article 121 LOSC 133

5.2.5 The Status of CCAMLR Seas 136

$\begin{array}{lll}5.3 \text { Formulating and Adopting conservation measures } & 140\end{array}$

$\begin{array}{ll}\text { 5.4 Status of CCAMLR as a Regional fisheries management organisation } & 142\end{array}$

$\begin{array}{lll}5.5 & \text { Previous tests to CCAMLR Authority } & 150\end{array}$

5.6 The development of the Patagonian Toothfish Fishery 152

5.6.1 The Patagonian Toothfish - Statistics and Habitat 152

5.6.2 Discovery of the Toothfish 154

5.6.3 Concerns about IUU fishing 154

$\begin{array}{ll}\text { Annex A to Chapter } 5 & 158\end{array}$

Chapter 6 The CCAMLR Response to IUU Fishing 161

$\begin{array}{lll}6.1 & \text { Introduction } & 161\end{array}$

6.2 CCAMLR Catch Documentation Scheme 161

6.2.1 Objectives and Application 161 
6.2.2 Supporting Conservation Measures $\quad 163$

6.2.3 Success of the CDS 163

6.2.4 Verification of CDS Documentation 166

$\begin{array}{ll}\text { 6.2.5 WTO Considerations } & 169\end{array}$

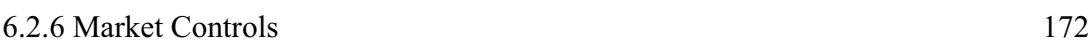

6.3 CCAMLR IUU Vessel Lists 174

$\begin{array}{ll}\text { 6.3.1 Legal basis } & 174\end{array}$

6.3.2 The Establishment of the CCAMLR IUU Lists $\quad 175$

6.3.3 Criteria and Procedure for listing vessels 176

6.3.4 Australian proposals for improvements to the IUU Vessel List 177

6.4 CCAMLR Licensed Vessel List 179

6.5 CCAMLR Resolutions 179

$\begin{array}{ll}\text { 6.5.1 Regional Cooperation } & 180\end{array}$

6.5.2 Flag State Responsibility and Vessel Authorisation 181

$\begin{array}{ll}6.6 \text { Conclusion } & 181\end{array}$

$\begin{array}{lll}\text { PART } 5 & \text { National Measures: Australia } & 183\end{array}$

$\begin{array}{ll}\text { Introduction } & 185\end{array}$

$\begin{array}{lll}\text { Chapter } 7 & \text { The Management of Commonwealth Fisheries } & 187\end{array}$

7.1 The Heard and McDonald Islands' Australian Fishing Zone 187

7.1.1 Management of the Heard and McDonald Islands 187

7.1.2 The Heard and McDonald Islands' Fishing Zone 188

7.1.3 Location of the Heard and McDonald Islands' Fishing Zone 188

$\begin{array}{ll}7.2 \text { The Management of Commonwealth Fisheries } & 189\end{array}$

7.2.1 Management Framework 189

7.2.2 Fishery Management Policy for the Heard and McDonald
Islands' Fishing Zone

7.3 The Arrival of the IUU Fishing Fleet 192

Chapter 8 Australia's Response to IUU Fishing 195

$\begin{array}{lll}8.1 \text { Introduction } & 195\end{array}$

8.2 Australia's Surveillance and Enforcement Policy 195

$\begin{array}{ll}\text { 8.2.1 Responding to an escalating threat } & 195\end{array}$

8.2.2 More 'force' in enforcement or alternative measures? 198

8.2.3 The 2004/2005 Southern Ocean Policy 199

8.3 Giving Effect to International Instruments and Norms 200

$\begin{array}{ll}8.4 \text { Review of Fisheries Legislation } & 204\end{array}$

$\begin{array}{ll}\text { 8.4.1 Introduction } & 204\end{array}$

8.4.2 Fisheries offences applying to foreign fishing vessels 205 
8.4.3 The Forfeiture provisions of the Fisheries Management Act 209 The Aliza Glacial litigation $\quad 210$ $\begin{array}{ll}\text { The Volga litigation } & 214\end{array}$

$\begin{array}{ll}\text { 8.4.4 The effectiveness of the Forfeiture provisions } & 215\end{array}$

$\begin{array}{lll}8.5 & \text { Further legislative responses } & 218\end{array}$

8.5.1 The recovery of costs incurred in pursuit 219

8.5.2 Relaxation of obligation to show identification under section 84(6) 221

$\begin{array}{lll}8.6 \text { Port controls } & 222\end{array}$

8.7 Market State Measures 223

8.8 Publication of arrests 223

8.9 Cooperation between States 226

8.9.1 Cooperative surveillance and enforcement 226

$\begin{array}{ll}\text { 8.9.2 Information Sharing } & 227\end{array}$

8.9.3 Bilateral treaty between Australia and France 228

8.9.4 Negotiations for cooperative surveillance with South Africa 229

8.9.5 Coalition of East Antarctic States $\quad 229$

$\begin{array}{ll}\text { 8.10 Bilateral Hot pursuits } & 230\end{array}$

8.11 Diplomatic Action (and sharing resources) 234

8.12 Control of nationals and flag vessels $\quad 235$

$\begin{array}{ll}8.13 \text { Records of fishing vessels } & 236\end{array}$

$\begin{array}{ll}8.14 \text { Conclusion } & 239\end{array}$

$\begin{array}{ll}\text { PART } 6 \text { Conclusion } & 241\end{array}$

Introduction 243

Chapter 9 Measures to deter IUU Fishing in the Southern Ocean in 245 the Absence of Flag State Control

9.1 Port State Controls 245

$\begin{array}{ll}\text { 9.1.1 The Benefits of Port State controls } & 245\end{array}$

9.1.2 Evaluating and Improving port State control 247

$\begin{array}{ll}\text { Short term improvement strategies } & 247\end{array}$

Long Term Improvement Strategies $\quad 249$

9.2 Market State Controls 251

9.2.1 The Benefits of Market State controls 251

9.2.2 Evaluating and Improving Market State control 252

Compliance with WTO Requirements 253

IUU Vessel or FOC Registers 254

Licensed Vessel List 254

$\begin{array}{ll}9.3 \text { Regional cooperation } & 254\end{array}$

9.3.1 National Measures $\quad 255$

$\begin{array}{ll}9.4 \text { Conclusion } & 256\end{array}$ 
Legislation

Bibliography

Index 


\section{Abstract}

Overfishing threatens the viability of high seas living resources. Furthermore, controls to prevent overfishing are inadequate. Illegal, Unreported and Unregulated (IUU) fishing is a product of overfishing and affects all marine fisheries. Southern Ocean fisheries have been particularly targeted by IUU fishing. The efforts of the CCAMLR Commission and the Australian government to adopt complementary measures to deter IUU fishing in the Southern Ocean form the basis of this study, although the examination is conducted following a comprehensive review of the legal and other factors contributing to the development of IUU fishing as well as the applicable international law.

The conclusions reached in the final Chapter are that in the absence of flag State control, alternative measures and strategies have proved to be effective in influencing the behaviour of IUU fishing vessels. By improving coastal State surveillance, enhancing regional cooperation, imposing port and market State controls, establishing IUU vessel databases and vigorously prosecuting offenders, RFMOs and coastal States can jointly increase the risk of conducting IUU fishing activities. At the same time financial returns can be diminished so that engaging in IUU fishing becomes economically unattractive. It is concluded that the application of a combination of these measures is required in order to achieve a degree of success in deterring IUU operators.

This study is up to date in law and facts to 30 October 2005. 


\section{Acknowledgements}

When one contemplates undertaking a research exercise of the magnitude required to produce a text of this type, I think it is easy to underestimate the impact it will have, not on your academic life but on your 'other' life. I talk of the important people in your life such as family and friends. As I became more single minded in my determination to complete my research, I also became harder to live with. The phrase, 'It won't be so bad when I've finished the book' was one that was greeted with a mix of amusement and resignation in my house.

I must thank my supportive husband Hugh who did not say a word when I announced my plan, when four months pregnant with child No. 2, to embark upon the $\mathrm{PhD}$ research which ultimately led to this book. Child No. 2 and No. 3 have come and grown and he remains supportive. So too have my three dear children who put up with 'cranky mummy' or 'distracted mummy'. They have given up asking when the fish book will be done and have ceased submitting fish illustrations for inclusion.

I should also acknowledge the academic support I received along the way in the form of experts willing to read and comment on my work. To this end I thank Professor Gillian Triggs (the Director of the British Institute for International and Comparative Law) Dr Michael White (T.C Beirne School of Law, University of Queensland) Dr Denzil Miller (Executive Secretary CCAMLR). To the many other people who assisted me along the way, I remain indebted to you. 


\section{Abbreviations}

Abbreviation

AAD

AFZ

CCAMLR

CDS

Code of Conduct

Compliance

Agreement

Conservation

Convention

EC/EU

EEZ

CITES

FAO

GATT

ICJ

ILC

IPOA-IUU

IMO

\section{Full Name}

Australian Antarctic Division

Australian Fishing Zone

Convention on the Conservation of Antarctic Marine Living Resources

Catch Documentation System

Code of Conduct for Responsible Fisheries 1995

Agreement to Promote Compliance with International Conservation and Management Measures by Fishing Vessels on the High Seas 1993

1958 Convention on Fishing and Conservation of Living Resources of the High Seas

European Community/European Union

Exclusive Economic Zone

Convention on International Trade in Endangered Species 1976

Food and Agriculture Organisation

General Agreement on Tariffs and Trade 1947

International Court of Justice

International Law Commission

International Plan of Action- Illegal, Unreported and Unregulated Fishing 2001

International Maritime Organisation 
ISOFISH International Southern Ocean Long line Fisheries Information Clearing House

ITLOS International Tribunal for the Law of the Sea

IUU Fishing Illegal, Unreported and Unregulated Fishing

IWC International Whaling Commission

LOSC Law of the Sea Convention 1982

NAFO Northwest Atlantic Fisheries Organisation

NGO Non-Governmental Organisation

OECD Organisation for Economic Cooperation and Development

RFMO Regional Fisheries Management Organisation

UN United Nations

1992 UNCED United Nations Conference on the Environment and Development 1992

UNCLOS III Third United Nations Convention on the Law of the Sea

UN Fish Stocks

Agreement

USA

USSR

VMS

WTO
United Nations Agreement for the Implementation of the Provisions of the United Nations Convention on the Law of the Sea of 10 December 1982 relating to the Conservation and Management of Straddling Fish Stocks and Highly Migratory Fish Stocks 1995.

United States of America

Union of Soviet Socialist Republics

Vessel Monitoring System

World Trade Organisation 


\section{Tables, Graphs and Maps}

\section{Chapter 1}

Graph 1.1

Table 1.1

\section{Chapter 3}

Graph 3.1

75

\section{Chapter 4}

$\begin{array}{lr}\text { Table } 4.1 & 90,91 \\ \text { Table 4.2 } & 98 \\ \text { Annex A to Chapter } 4 & 117\end{array}$

\section{Chapter 5}

Map 5.1

129

Table 5.1

130

Annex A to Chapter $5 \quad 158$

\section{Chapter 6}

$\begin{array}{cc}\text { Table } 6.1 & 180 \\ \text { Table } 6.2 & 182\end{array}$

\section{Chapter 7}

Table 7.1

193

\section{Chapter 8}

$\begin{array}{cc}\text { Table } 8.1 & 208 \\ \text { Table } 8.2 & 218 \\ \text { Table } 8.3 & 225 \\ \text { Table 8.4 } & 233 \\ \text { Table 8.5 } & 238 \\ \text { Map 8.1 } & 240\end{array}$

